compound at each end of the cylinder, and the dialysis fluid flows between them via connectors in the cylinder wall.

Dermatitis has been reported in four patients using haemodialysis equipment. ${ }^{3}$ Three of them underwent patch tests, which showed a positive response to thiuram compounds; a further four patients had positive reactions to thiuram on patch testing but no dermatitis. Patch tests with the components of the apparatus gave negative results. Our patient showed a positive reaction to thiuram but did not react to patch tests with components of his equipment.

Hillman et al reported that a plasticiser from a neonatal catheter had been detected in neonatal tissue ${ }^{4}$ and suggested that rubber chemicals are dissolved in the course of haemodialysis to produce sensitisation. We believe that a similar mechanism operated in our patient. Thiuram and carbamate compounds are present in rubber in a concentration of $0 \cdot 125-0 \cdot 30 \%$ and are a common cause of sensitivity to rubber. ${ }^{5}$ They are normally insoluble in water but can be dissolved in acetone, benzene, and carbon tetrachloride. It is of interest that an allergic reaction developed in a patient who had rejected three renal transplants. This suggests that he might have an unusually strong type IV immunological response.

${ }^{1}$ Cronin E. Contact dermatitis. Edinburgh: Churchill Livingstone, 1980.

2 Wilson HTH. Rubber dermatitis. Br 7 Dermatol 1969;81:175-9.

${ }^{3}$ Pennys NS, Edwards LS, Katsikas JL. Allergic contact sensitivity to thiuram compounds in a haemodialysis unit. Arch Dermatol 1976; 112:811-3.

1 Hillman LS, Goodwill SL, Sherman WR. Plasticizer in neonatal tissue after umbilical catheterization. $N$ Engl f Med 1975;292:381-6.

${ }^{5}$ Gaul EI. Results of patch testing with rubber antioxidants and accelerators. F Invest Dermatol $1957 ; \mathbf{2 9}: 105-10$

(Accepted 20 fuly 1983)

Department of Dermatology, Royal infirmary, Edinburgh EH3 9YW P K BUXTON, MRCP, FRCPC, consultant

S M GOING, $M B, M R C P$, registrar

J A A HUNTER, MD, FRCPED, professor

Medical Renal Unit, Royal Infirmary, Edinburgh EH3 9YW

R J WINNEY, MB, FRCPEN, consultant renal physician

\section{Acute hypotensive response to nifedipine added to prazosin in treatment of hypertension}

Nifedipine is a calcium antagonist that is increasingly used in antihypertensive treatment. ${ }^{2}$ Excess hypotension or left ventricular depression was initially thought to be hazardous in patients already receiving beta adrenoceptor blockade, ${ }^{3}$ although the combination is now known to be generally safe. ${ }^{2}$ We report two cases in which administration of nifedipine with prazosin caused an acute hypotensive response; reactions to the two drugs were subsequently studied in eight further patients.

\section{Case reports}

Case 1-A 42 year old man with essential hypertension was being treated with atenolol, prazosin, and a thiazide diuretic, but control was inadequate. A nifedipine placebo capsule was administered one hour after a dose of prazosin $5 \mathrm{mg}$, and no change in blood pressure occurred. Then $10 \mathrm{mg}$ active nifedipine was given sublingually; after 20 minutes his blood pressure had fallen from $200 / 120 \mathrm{~mm} \mathrm{Hg}$ supine and $232 / 124 \mathrm{~mm} \mathrm{Hg}$ standing to $150 / 78 \mathrm{~mm} \mathrm{Hg}$ supine and $88 / 48 \mathrm{~mm} \mathrm{Hg}$ standing (figure). He complained of dizziness and recovered spontaneously. He was twice rechallenged with the nifedipine and prazosin combination, once after six weeks without taking atenolol to exclude the possibility of an adverse interaction between nifedipine and beta adrenoceptor blockade. ${ }^{3}$ On both occasions the initial systolic pressures were over $200 \mathrm{~mm} \mathrm{Hg}$ and the diastolic pressures about $120 \mathrm{~mm} \mathrm{Hg}$. When nifedipine was administered soon after a dose of prazosin standing systolic pressures fell to under $100 \mathrm{~mm} \mathrm{Hg}$ (figure), with spontaneous recovery.

Case 2-A 44 year old man with a history of severe hypertension and unstable angina pectoris, whose supine blood pressure was 200/140 $150 \mathrm{~mm} \mathrm{Hg}$, was being treated with rauwolfia serpentina, methyldopa, and nifedipine all twice daily. He was treated with prazosin $2 \mathrm{mg}$ to reduce his blood pressure, but this was ineffective so the dosage was repeated. The response was considered to be inadequate, and $20 \mathrm{mg}$ nifedipine was administered sublingually. His blood pressure fell rapidly to $110 / 70 \mathrm{~mm} \mathrm{Hg}$ and he was distressed and sweating, with tachycardia and further chest pain. He was kept supine and spontaneous recovery followed.

Other cases-These severe interactions stimulated further studies. Eight patients with uncontrolled hypertension were given prazosin and nifedipine as described above. Mean (SEM) control blood pressures in this group were $210 / 110(7 / 6) \mathrm{mm} \mathrm{Hg}$ supine and $204 / 116(10 / 6) \mathrm{mm} \mathrm{Hg}$ standing. These values were unchanged one hour after administration of prazosin. Twenty minutes after the patients were given nifedipine placebo mean blood pressures were 198/108 (6/3) $\mathrm{mm} \mathrm{Hg}$ supine and $192 / 114(8 / 5) \mathrm{mm} \mathrm{Hg}$ standing. Twenty minutes after administration of active nifedipine pressures were $173 / 96(6 / 5) \mathrm{mm} \mathrm{Hg}$ supine and $168 / 97(8 / 3) \mathrm{mm} \mathrm{Hg}$ standing (figure).

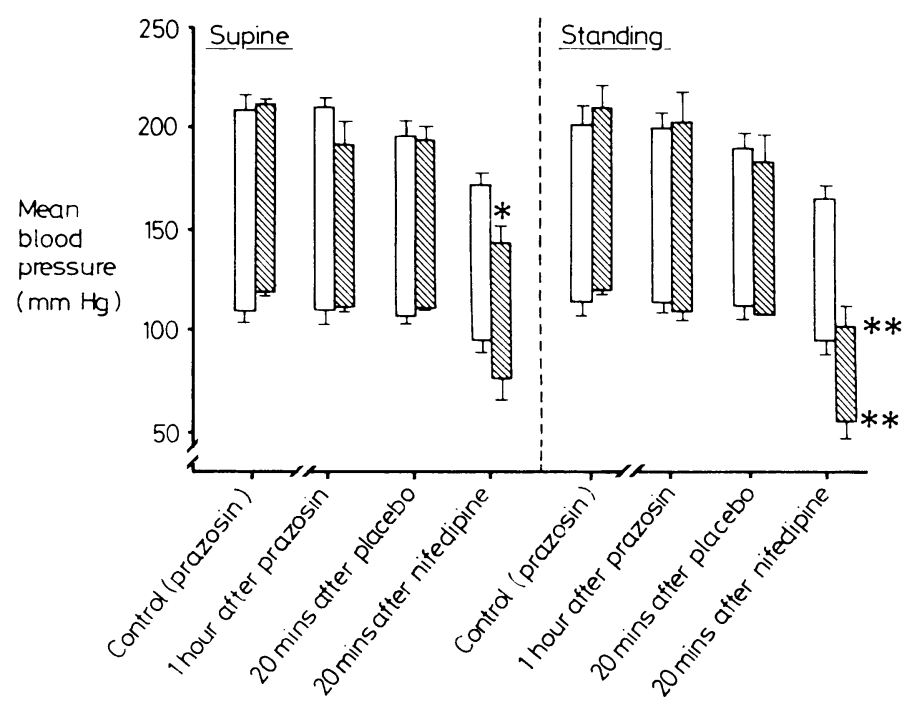

Mean (SEM) blood pressures in eight patients given nifedipine and prazosin (open columns) compared with mean pressures in a patient sensitive to the combination who was challenged on three occasions. ${ }^{*} \mathrm{p}<0.05 ;{ }^{* *} \mathrm{p}<0.005$.

\section{Comment}

We are not aware of studies directed at the possible added hypotensive effects of calcium antagonists such as nifedipine and alpha antagonists such as prazosin. The fact that two of the 10 patients reported on here showed adverse effects to the combination leads us to suggest that great care should be taken in prescribing additive treatment with these two drugs. When nifedipine is added to prazosin it should be given as a $5 \mathrm{mg}$ dose with the patient recumbent and carefully observed. Conversely, when prazosin is given to patients already receiving nifedipine a test dose of $0.5 \mathrm{mg}$ should be given while the patient is recumbent. Both prazosin and nifedipine are valuable antihypertensive agents, probably acting on different receptors in vascular smooth muscle ${ }^{4}$; This report argues against their combined use except in carefully monitored circumstances.

${ }^{1}$ Guazzi MD, Fiorentine C, Olivari MT, Bastorelli A, Necchi G, Polese A. Short- and long-term efficacy of a Ca-antagonistic agent (nifedipine) combined with methyldopa in the treatment of severe hypotension. Circulation 1980;61:913-9.

2 Opie LH, Jee L, White D. Antihypotensive effect of nifedipine combined with cardioselective beta-adrenergic receptor antagonism by atenolol. Am Heart f 1982;104:606-12.

${ }^{3}$ Opie LH, White DA. Adverse interaction between nifedipine and $\beta$ blockade. Br Med f 1980;281:1462-4.

${ }^{4}$ Van Zwieten PA, Van Meel JCA, de Jonge A, Wilffert B, Timmermans PBMWM. Central and peripheral a-adrenoceptors. $f$ Cardiovasc Pharmacol 1982;4:519-24.

(Accepted 1 August 1983)

Heart Research Unit, Medical School, University of Cape Town, and Hypertension Clinic, Groote Schuur Hospital, Cape Town, South Africa

L D JEE, $M B, C H B$, research registrar

L H OPIE, MD, FRCP, professor

Correspondence to: Professor L H Opie. 